\title{
The Corpus of Russian Translations of Social and Political Works of the Eighteenth Century
}

\author{
Sergey Polskoy \\ The Higher School of Economics (Moscow) \\ s.polskoy@gmail.com \\ Vladislav Rjéoutski \\ Deutsches Historisches Institut Moskau \\ vladislav.rjeoutski@dhi-moskau.org
}

\begin{abstract}
:
The project that has been carried out at the German Historical Institute in Moscow since 2016 continues the engagement of the Institute in the development of the history of concepts in Russia. The previous project, "The History of Concepts and Historical Semantics," which was led by Ingrid Schierle and Denis Sdvizkov (both research fellows at the German Historical Institute in Moscow at the time), was undertaken between 2008-2014. It consisted of a series of conferences and resulted in several publications; namely, two volumes devoted to the history of key concepts in the Russian imperial period. ${ }^{1}$ However, the main focus of the current project is on translation as a laboratory of the Russian language of "civil sciences." The project is being coordinated by Sergey Polskoy (Higher School of Economics, Moscow) and Vladislav Rjéoutski (German Historical Institute in Moscow). In addition, the editorial work on the database is being carried out by Evgenii Kushkov (Higher School of Economics, Moscow), with Vadim Popov (GHI Moscow) also being responsible for statistics and the visualization of the results of the project.
\end{abstract}

Keywords:

conceptual history, translation, political language, book history, digital humanities

\section{Translation and the History of Concepts}

The well-known series of publications entitled Geschichtliche Grundbegriffe, which were coedited by Reinhart Koselleck and his collaborators, ${ }^{2}$ was the starting point for our project. Koselleck's idea was to undertake a sort of archaeology of the most important historical concepts that describe society, the main social groups, and relations between them, and to show the semantic changes that occurred in the meaning of the terms we use today. He wanted to understand what these words meant in the early modern period before they swiftly began to change their meaning around the 1770 .

The semantic changes that are revealed through this analysis testify to the appearance of a new understanding of society and our relations within it. In a very schematic way, the changes

\footnotetext{
${ }^{1}$ А. И. Миллер, Д. Сдвижков, И. Ширле (ред.), “Понятия о России”: К исторической семантике имперского периода, в 2 т. (Москва: Новое литературное обозрение, 2012). (A. I. Miller, D. Sdvizkov, I. Schierle (red.), "Poniatiia o Rossii": K istoricheskoi semantike imperskogo perioda, v 2 t. (Moscow: Novoe literaturnoe obozrenie, 2012).

${ }^{2}$ Geschichtliche Grundbegriffe; historisches Lexikon zur politisch-sozialen Sprache in Deutschland. Hrsg. von Otto Brunner, Werner Conze [und] Reinhart Koselleck. 8 vols. (Stuttgart: E. Klett 1972-1997).
} 
detected by Koselleck and his team in the basic concepts in the German-speaking world can be described as democratization, temporalization, ideologization and politicization. This means that political concepts not only started to be used by social elites, but also by extended circles of speakers, which was the result of the growing number of publications that were read by the general public. Thus, traditional concepts can now be charged with expectations and even emotions; they possess a multilayered structure that can be composed of elements from the past, present, and future. The increasing abstraction of concepts leads to the possibility of charging them with various ideologies and meanings, which often depend on the social position of the speaker.

The advantages of such a project for our understanding of the past and of the changes which occurred in our society during the modern era are obvious. Historians are the first to benefit from the results of the history of concepts because they become more aware of what the concepts that they are using to describe the past really mean and are less prone to transpose, often unconsciously, the meaning of today onto the realities of the past. The use of concepts with a full understanding of their meaning enables us to avoid anachronism, at least to a certain extent. ${ }^{3}$ As Melvin Richter states, by retrieving the language of the period being studied, we can better see the gap between it and the language of later historians and sociological analysts who work (or think they work) in terms of atemporal definitions. ${ }^{4}$ As Peter Burke notes, "even the most monoglot of historians is a translator."

Translation as such was not at the core of Koselleck's project. However, in the introduction to Geschichtliche Grundbegriffe, he did mention the importance of the translation of concepts as a means of making the historical experience visual, so to speak. The translation of texts was central to the great cultural movement of early modern Europe. ${ }^{6}$ Through translation, every society acquires new concepts to meet needs, whether real or imagined. ${ }^{7}$ In the case of Russia in the eighteenth century, we are dealing with a culture that remained relatively on the sidelines of the developments that were taking place elsewhere in Europe. Political vocabulary was poorly elaborated in the Russian language at the time. The same was true for many other fields. Vocabulary in the fields of the natural sciences, linguistics, and in many other domains was created mostly in the process of translation.

The idea that most of the terms that are now part of the political vocabulary of the Russian language were originally elaborated by translators is the starting point and one of the main theses of the project. In other words, the role of the translator is central in this process. Traditionally, as Magrit Pernau explains, translation was seen as "taking place between two languages, considered to be entities complete in themselves and endowed with stable boundaries." As a result of the cultural turn in translation studies, translators started to be seen as active and creative agents. They did not "find" equivalents between languages, but rather, created them. As stressed by Pernau, "translation thereby became a negotiated and contested undertaking, which was embedded in social interactions and power relations." The

\footnotetext{
${ }^{3}$ Melvin Richter, "Introduction: Translation, the History of Concepts and the History of Political Thought," in Why Concepts Matter: Translating Social and Political Thought, eds. Martin J. Burke \& Melvin Richter (Leiden: Brill, 2012), 12.

${ }^{4}$ Richter, "Introduction," 13.

${ }^{5}$ Peter Burke, "Cultures of Translation in Early Modern Europe," in Cultural Translation in Early Modern Europe, eds. Peter Burke \& R. Po-chia Hsia (Cambridge: Cambridge University Press, 2009), 7.

${ }^{6}$ Burke, "Cultures of Translation in Early Modern Europe," 10.

${ }^{7}$ Richter, "Introduction,” 10.
} 
translator introduced a concept from another language and embedded it in a new context, and through this process, he (or she, but mostly he at the time we are exploring) restructured the semantic field into which the word had been imported. In other words, translation transforms the target language. ${ }^{8}$

As shown by Sergey Polskoy, the "quality" of the terms created in Russian through translation depended hugely on the abilities of the translators, as well as their social experience and cultural and linguistic outlook. ${ }^{9}$ This was not only reflected in special shades of meaning that translators conferred on the terms they created in Russian, but also in the choice of a particular linguistic and intellectual tradition within which they thought such terms would be best expressed. In the first half of the eighteenth century, the clerks of the Muscovite chancelleries (prikazy) used bureaucratic vocabulary in their translations, while translators from among the clergy, finding no equivalents in Russian, mostly translated in a mixture of Church Slavonic and Polish.

\section{The Corpus of Russian Translations of Political Texts}

The central feature of the project is a database of political texts translated from various European languages into Russian in the eighteenth century. The database contains translations of essays that can be attributed to a wide range of knowledge in the humanities that were often referred to as "civil science" (scientia civilis) in the seventeenth and eighteenth centuries. It served to speak with a member of society ("citizen," "son of the fatherland," "statesman") about the purpose, history, structure, and control mechanisms of "civil society" (societas civilis) and the position of the citizen (civis). The boundaries of the political sphere of the eighteenth century are difficult to determine using modern concepts such as "sociology," "political science," "economy" or "law." The European "political" literature of the time is characterized by the intersection of disciplinary discourses, while significantly maintaining a close relationship between the "scientific" and the literary text. Therefore, a political treatise during this period could be a collection of practical instructions (Machiavelli, Guicciardini, Ceriol), an emblem book containing a metaphorical description of the "positions" held by the sovereign and his or her subjects (Saavedra Fajardo), a political novel (Fénelon) and a pamphlet (Boccalini), or a collection of historical examples of specific political "cases" (Lipsius, Bessel, Fredro). In other words, at the time the political book could include texts that are now classified as modern social philosophy, political theory, history, economics, literary works of a political nature (political novels, pamphlets, opinion journalism, etc.), as well as guidelines, handbooks, dictionaries, and tutorials that we would now attribute to these disciplines. Indeed, we did not wish to impose our contemporary understanding of the political, but rather tried to grasp how this field was understood by people at the time.

Work on the database included the following stages: First, we selected translations that, to our minds, contained political vocabulary. We were guided in this task by our broad definition of the political, but of course, our selection is subjective. We commissioned a certain number

\footnotetext{
${ }^{8}$ Margrit Pernau, "Whither Conceptual History? From National to Entangled Histories," Contributions to the History of Concepts, vol. 7, Issue 1 (Summer 2012): 6-7.

${ }^{9}$ Sergey Polskoy, "Translation of Political Concepts in 18th-Century Russia: Strategies and Practices," Kritika: Explorations in Russian and Eurasian History, vol. 21, no. 2 (Spring 2020): 235-265.
} 
of detailed descriptions of translations, both printed and in manuscript form. We were open to suggestions from our colleagues. For example, one colleague spotted a number of manuscript translations in Kyiv, and we included these in our database.

The main sections of the website are "Translations," "Authors," "Glossary of Concepts," and a the searchable "Database" itself.

\section{Translations}

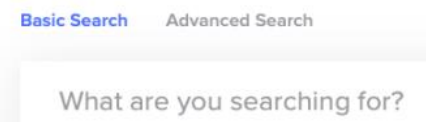

Search

Alphabetical Index

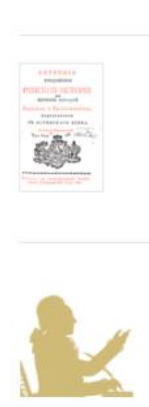

А Б В Г Е 3 И Л М Н О П Р С Т Ф Ц ч Ш $Э$ Ю

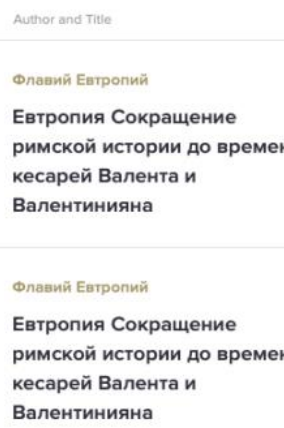

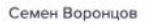

Семен Воронцов

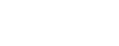

Семен Воронцов

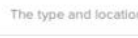

- печатный

Москва

1] печатный

१осква

As its title suggests, the first section provides access to a list of translations. For the most important texts, we not only offer a detailed description, but also fragments of the translation, including key political concepts. These fragments are given in parallel with excerpts from the original text, as scholars often need to compare the translated term with the original. Original and translated terms are highlighted in the text: by clicking on a term (for example, "общество" in the article "Economics (morality and politics)" by J.-J. Rousseau, from the Encyclopédie, ou Dictionnaire raisonné des sciences, des arts et des métiers, one can access all the excerpts of political texts that contain this term. The website offers many pages of examples for some frequently used terms.

These are only samples, however, because the idea was to present in a concise way the main political vocabulary that can be found in a given text. In most cases, the context provided was deliberately broad: we tried to produce meaningful phrases, often whole passages, in order to avoid any ambiguity in the context. We often deal with loanwords. As Pernau stresses, to become understandable, a loanword needs to be explained with words already known to readers: 'This process links the concepts to their linguistically embodied experiences, and thereby bridges the gap between self and other and colors the meaning of the word in its new context."10

Of course, the idea that by providing a context we can always clearly understand the shades of meaning of a term used by a translator is illusory. Translation, as Peter Burke rightly

\footnotetext{
${ }^{10}$ Pernau, "Whither Conceptual History?," 6-7.
} 
stresses, is a constant negotiation of meaning. Moreover, translators in the eighteenth century often acknowledged the possibility and the need to adjust and reframe the original text, because one of the criteria of a good translation was the measure to which the text was adapted to a target audience. When Mazel translated Locke into French, for example, he no doubt consciously adapted Locke to the French context through his choice of terms in order to show that the monarch and the people were at war in France. ${ }^{11}$ However, in many cases, the context is really helpful.

\section{Authors}

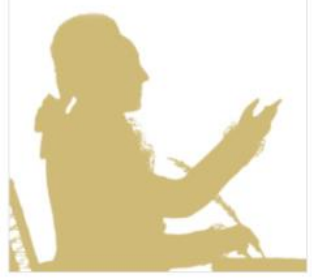

Jacques Accarias de Serionne Жак Аккария де Серионн

1706-1792?

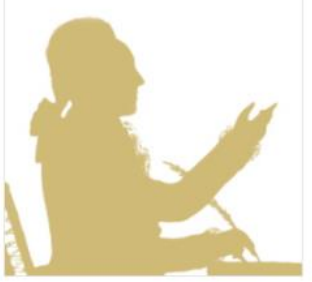

Gottfried Achenwall Готфрид Ахенвалль

$1719-1772$

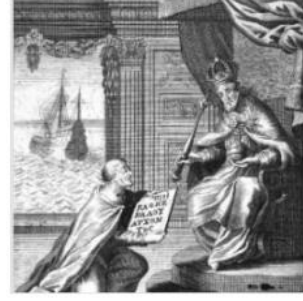

Ayanntòs / Agapetus Агапит

VI B

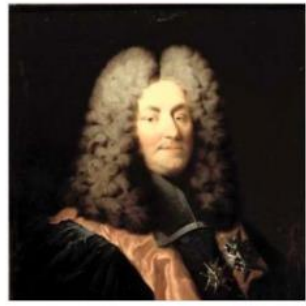

Henri François d'Aguesseau Анри Франсуа д A'Arecco

$1668-1751$
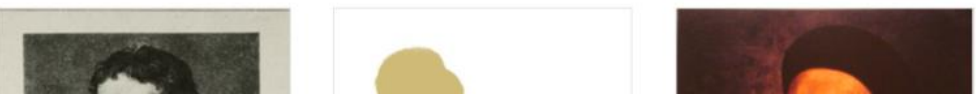

This page provides a means to easily access the list of authors of works presented on the site (they can be searched in both the general list and through the Latin and Russian alphabet; an advanced search can also be used). By going to the author's page (e.g. Joost Lips), the user can find a list of the author's original works that were translated into Russian, as well as the titles of the Russian translations of the texts, the descriptions of which can be found on the website. In the case of Lips (or Lipsius), we have only one translated work, but a whole range of translations, or rather copies of translations, can be found in various archives in Russia. This testifies to the popularity of this work in Russia at the time. In the case of sample texts being presented on the site, this is indicated by an icon in the list of Russian translations $\stackrel{\text { Aa }}{=}$.

\footnotetext{
${ }^{11}$ S.-J. Savonius, "Locke in French: The Du Gouvernement Civil of 1691 and its Readers," The Historical Journal, vol. 47, no. 1 (March 2004): 47-79.
} 


\section{Glossary}

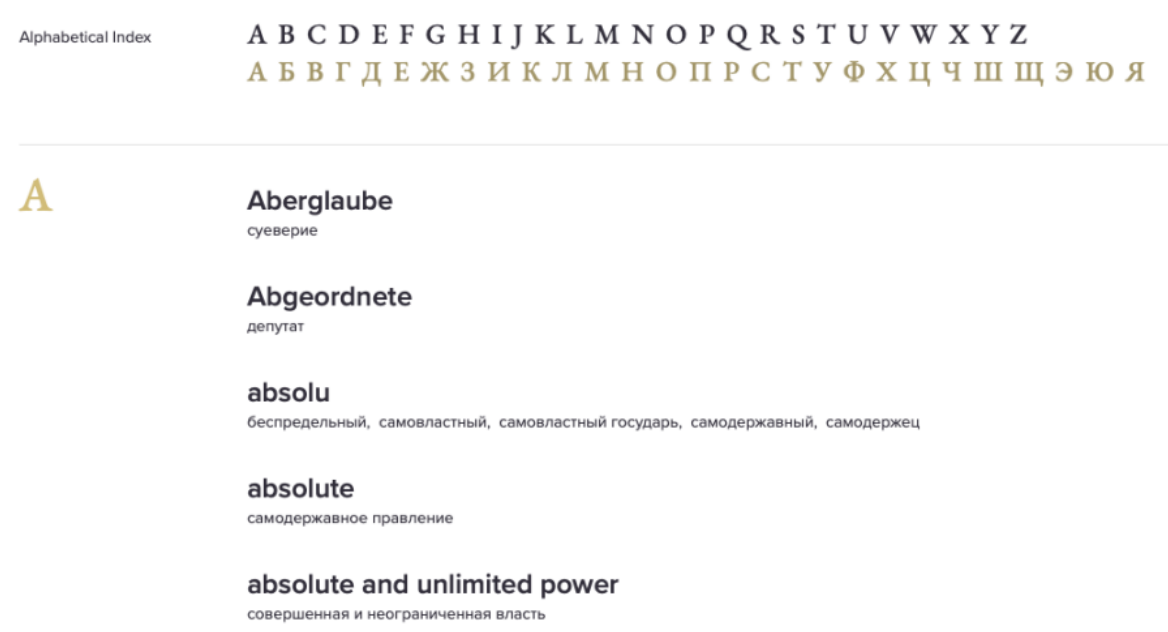

This is a list of all the political terms found in the text fragments presented on the website. The list includes both the original terms (in a multitude of European languages) and their Russian equivalents. By clicking on any of the terms, the user will access the equivalents found in the original works or in Russian translations respectively. It is also possible to conduct a keyword search in the search bar (e.g. "constitution") and to find all related terms.

Excerpts containing highlighted terms can be found below the search bar. All the excerpts are followed by the title of the work from which they were taken, as well as the date of publication. Russian translations are deliberately arranged in chronological order, which allows the user to see how the meaning of each term evolved throughout the eighteenth century. By exploring the term in the chronological order of contexts, the user is better able to grasp the changes which occurred (or, in some cases, did not occur) in the meaning of each term. 
Basic Search Advanced Search

Keyword search

Full-text search

Enter a word or a phrase

\begin{tabular}{l|l|l} 
OR $\quad \checkmark \quad$ Full-text search $\quad \checkmark \quad$ Enter a word or a phrase \\
\hline
\end{tabular}

$\times$

+ Add additional condition

By years of publication

c

По

\begin{tabular}{ll|l|l|}
\hline 1680 & $\hat{2}$ & 1820
\end{tabular}

Language

Publication type

Any language

Any

\section{Search}

Given this is a searchable database, the search bar is an important tool. In our database, it is possible to undertake a search using either basic or advanced search term options, as is usually the case in library catalogs. But there is one feature that we implemented that is not usually found in library catalogs. For example, if users only select manuscripts, then they will find all the manuscripts featured on the website. It is also possible to search by language. For example, a search using "English" as a keyword, results in only 13 hits (clearly an unknown language in eighteenth-century Europe!), whereas "French" leads to nearly 900 matches.

There are some other sections on the website that serve to facilitate use of the database. For example, we have a section on "frequently asked questions." We have also provided a section on "project news." Finally, we have added an "add translations" template in order to facilitate feedback and to learn about new translations that could be included in our database.

Translations: Directions for Use 


\section{Text example}

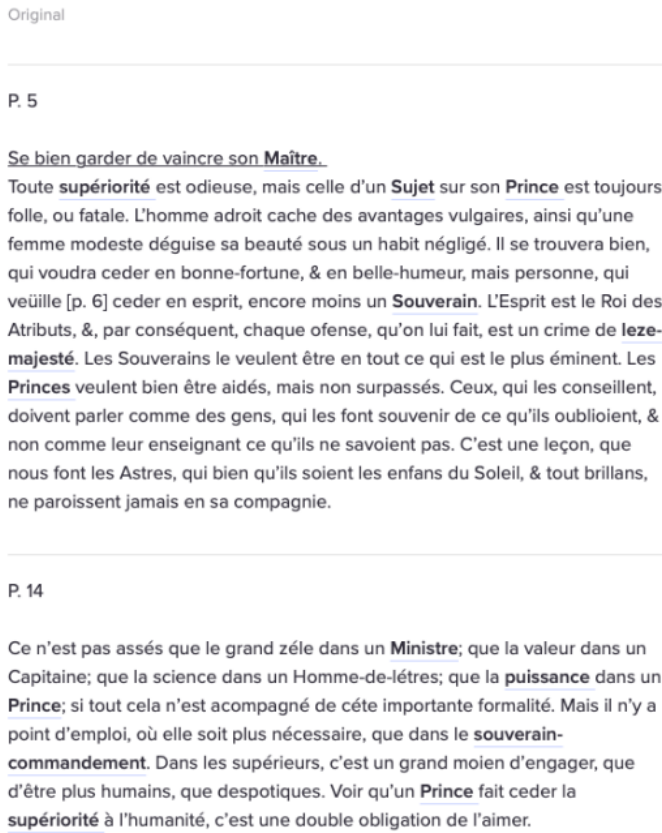

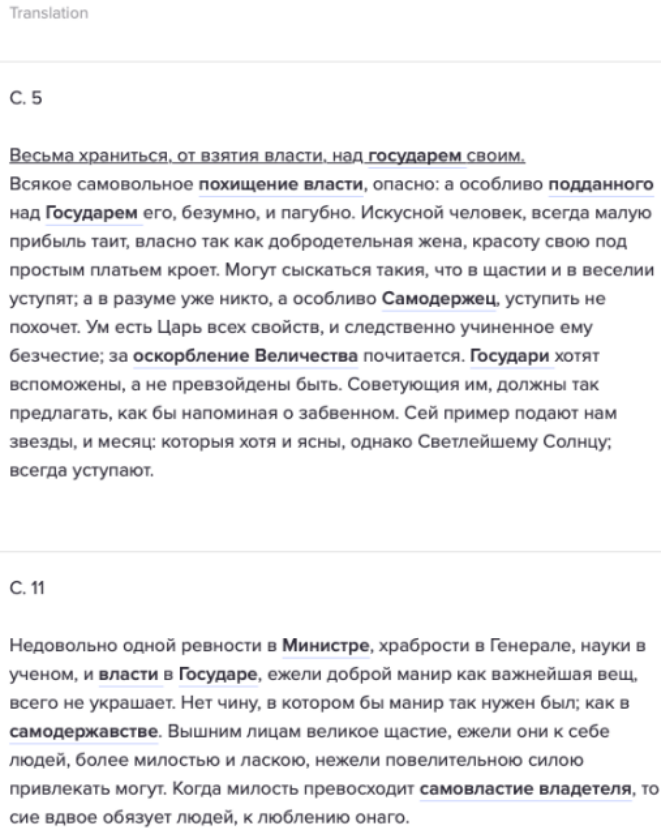

Недовольно одной ревности в Министре, храбрости в Генерале, науки в ученом, и власти в Государе, ежели доброй манир как важнейшая вещ. всего не украшает. Нет чину, в котором бы манир так нужен был; как в самодержавстве. Вышним лицам великое щастие, ежели они к себе людей, более милостью и ласкою, нежели повелительною силою привлекать могут. Когда милость превосходит самовластие владетеля, то сие вдвое обязует людей, к люблению онаго.

Let us give an example of how this organization of material can work. By choosing a term in Russian or in a source language, it is possible to see how one term was translated into Russian in various contexts; or what meanings from the original terms a particular Russian term could vehiculate. The transformations of the German term "Bürger" and the French word "citoyen" are demonstrated below.

\section{Glossary > Bürger

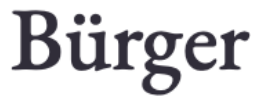

гражданин, мещанин, мещанство, подданный

"Bürger" is basically translated into Russian by three terms: "гражданин," “мещанин" and "подданный." Each word reflects different meanings of the German term: the inhabitant of a town or city; the member of a society, or of a people; and the subject of a monarch. "Гражданин" was also used in the sense "inhabitant of the city" in the eighteenth century, but by the second half of the century its primary meaning had become "member of a given society." The influence of French was very important here. The three meanings in French are expressed by different words ("citoyen," "bourgeois," and "sujet"). However, the word "citoyen" also meant "inhabitant of a city" and in this sense it was a synonym of "bourgeois" (definition given by Dictionnaire de l'Académie Française, 1694). ${ }^{12}$ It was in the course of the eighteenth century that the word changed its meaning to become a synonym of "patriot" ("le bon citoyen"), or

12 “Citoyen, Enne, s.," Dictionnaire de l'Académie française, accessed November 23, 2021, https://www.dictionnaire-academie.fr/article/A1C0407-03. 
came to refer to somebody who was not only an inhabitant of a city or country, but who was also concerned with the interests of their country and fellow-citizens. Hence, the earlier meaning of the word became obsolete. In the Dictionnaire critique de la langue française (1787) we can already read that the word is not used in the expression "citoyen de Paris" (inhabitant of Paris). ${ }^{13}$ The new meaning "patriot" can be seen in many translations of this word in our database from the 1760 s. Thereafter, the word was invariably translated as "гражданин." Six pages of examples on our website demonstrate how extensive the use of this word had become by the second half of the eighteenth century, that is, in the decades before the French Revolution. Moreover, these examples show how these translations influenced the Russian word by detaching it from its earlier use, in the sense of a "city inhabitant," exactly as in the case of the French term, and by bonding it with this new meaning.

In such examples, which are numerous in our database, Russian concepts coined under the influence of Western European notions in the process of translation announce some future project. This is particularly so in the Russian context, because many of these political concepts were inapplicable within the old system of ideas about the state and the monarch.

\section{Statistics and Visualization}

When we began this new project initiative, we assumed that some statistical data concerning the evolution of publishing in eighteenth-century Russia was already available. We soon found out, however, that no precise data is available regarding the increasing number of publications, the composition of the corpus of published books, the part of translations in it, and the distribution of translations per original language. ${ }^{14}$ This new data will be of great interest for the field of Russian eighteenth-century studies, as well as comparative studies on book culture in Europe and throughout the world. ${ }^{15}$

\footnotetext{
${ }^{13}$ Dictionnaire critique de la langue française. Tome premier, A-D, par., M. l'abbé Feraud, (Paris, 1787), 452.

${ }^{14}$ One of a few attempts to calculate the number of translations into Russian was undertaken by Gary Marker. See Gary Marker, Publishing, Printing, and the Origins of the Intellectual Life in Russia, 1700-180o (Princeton: Princeton University Press, 1985), 88. See also the data published by K. Bugrov and M. Kiselev (partly on the basis of statistics compiled by G. Marker) in К. Д. Бугров и М. А. Киселев, Естественное право и добродетель: интеграция европейского влияния в российскую политическую культуру XVIII века (Екатеринбург: Издательство Уральского университета, Университетское издательство, 2016), 20-23 (K. D. Bugrov i M. A. Kiselev, Estestvennoe pravo i dobrodetel': integratsiia evropeiskogo vliianiia v rossiiskuiu politicheskuiu kul'turu XVIII veka (Ekaterinburg: Izdatel'stvo Ural'skogo universiteta, Universitetskoe izdatel'stvo), 20-23).

${ }^{15}$ See "Statistics \& Charts," The Corpus of Russian Translations. Deutsches Historisches Institut, accessed December 9, 2019, https://krp.dhi-moskau.org/en/page/stats.
} 


\title{
Translations and languages
}

\begin{abstract}
This section provides information on the share of translated and original Russian works in the overall volume of civil script publications in the eighteenth century. The category "Translations of Social and Political Works" refers to the texts included in the Corpus of Russian Translations. The last graphs show data on the role of intermediary languages of translation in the total number of translated books - for all books in civil script before 1800 and separately for publications included in the Corpus of Russian Translations.
\end{abstract}

Shares of original Russian publications and Russian translations, 1708-1800

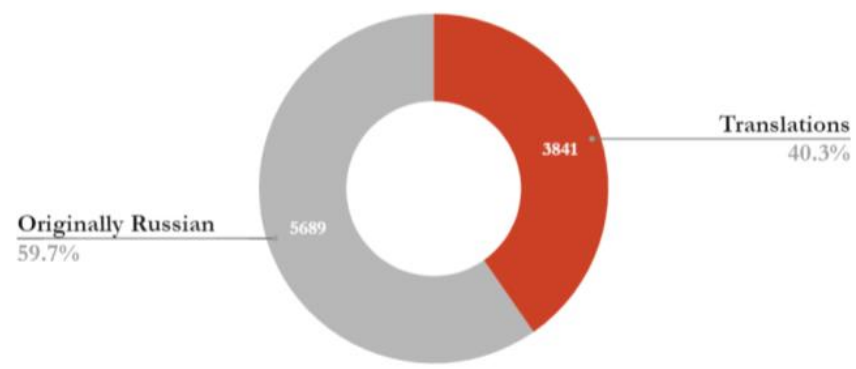

Nearly ten thousand books were published in Russia in the eighteenth century. About $40 \%$ (or roughly 3800) of the texts in this corpus were translations. Our database lists nearly 500 titles, which therefore comprises about $5 \%$ of the overall total of books published in Russia in the eighteenth century, or about $13 \%$ of all the translations published in the country.

If we look at the distribution of languages among these translations, we see that French occupies a leading position. German was also a very important language in the field of translations in Russia at the time. All other languages, including Latin and English, are rather negligible in this regard. If we analyze the socio-political translations compared to this data, we see that if the percentage of translation from German is the same, the percentage of translations from French is much higher than among the general translations ( $54 \%$ and $46.5 \%$ respectively). Hence, there is a difference of $7.5 \%$, which is certainly more than the margin of error. It may be that in some of the categories covered by "political" literature, such as historical works, books in French were over-represented. However, it may also be due to the intermediary role played by the French language, as can be seen in our corpus.

The Total Number of Books Published in Russia in the Eighteenth Century/the Number of Translations

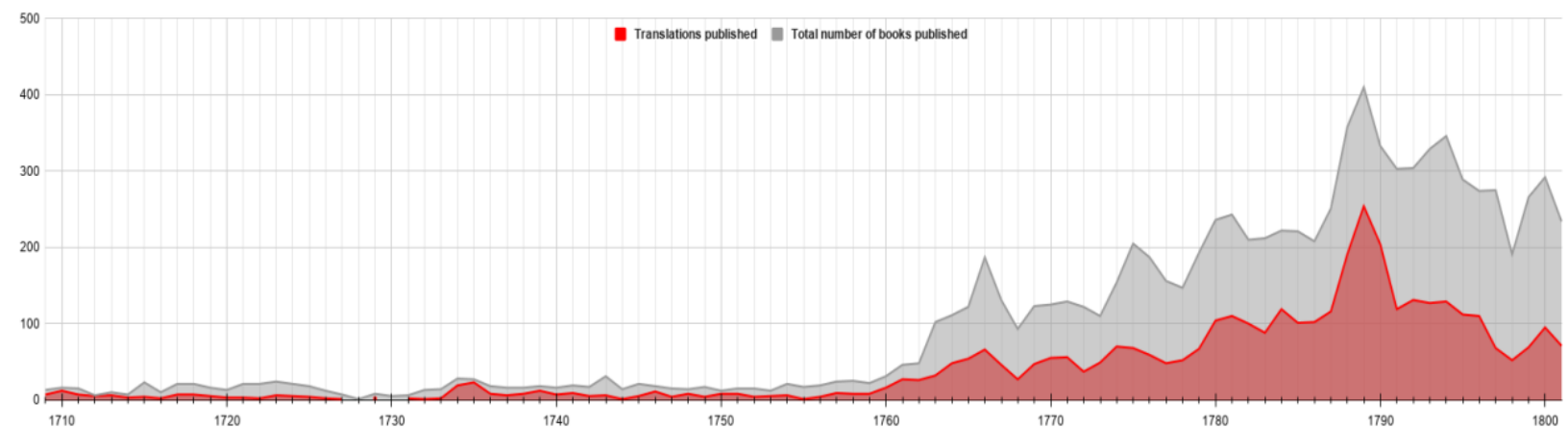


In chronological terms, the overall number of publications in Russia in 1762, that is, the year of the accession of Catherine II to the throne, was rather low, with about 30\% being accounted for by translations. In 1788, the year before the beginning of the French Revolution, the number of publications in Russia was four times higher (about 400), of which more than 250 were translations. We see that not only the overall number of translations increased enormously, but also that the number of translations was increasing more than the number of non-translated books. If, on average, translations constituted about $40 \%$ of all publications in Russia, in 1788 the proportion of translations peaked at roughly $62 \%$ of all books published that year. This changed in the following years, due to all manner of restrictions, which affected, first and foremost, books imported from France. This trend had already begun in the last years of Catherine's reign, but it worsened during the reign of Paul I.

If we look at how the number of translations into Russian evolved throughout the eighteenth century, then we see that the proportion of books translated from French and from German respectively was very different. In the first half of the century, the number of books translated from German was small, but still nearly always higher than works translated from French. The explosion in translations from French in the second half of the eighteenth century can be explained by the development of the use of French in Russian society, which began around the middle of the century. Yet, even in the second half of the century, German remained the main competitor to French. In the years preceding the French Revolution, the gap between the two increased considerably.

This attests to a growing interest in foreign literary and intellectual production. Interestingly, this general growth of interest in foreign books was not only evident in terms of French and German translations, but also Latin. English, on the other hand, only accounted for a paltry two to four translations each year up to the end of the century. Nonetheless, it would be wrong to conclude that there was no interest in Russia in publications coming from the British Isles, as books published in English were often translated into Russian from either French or German.

Role of intermediary languages in all translations into Russian, 1708-1800

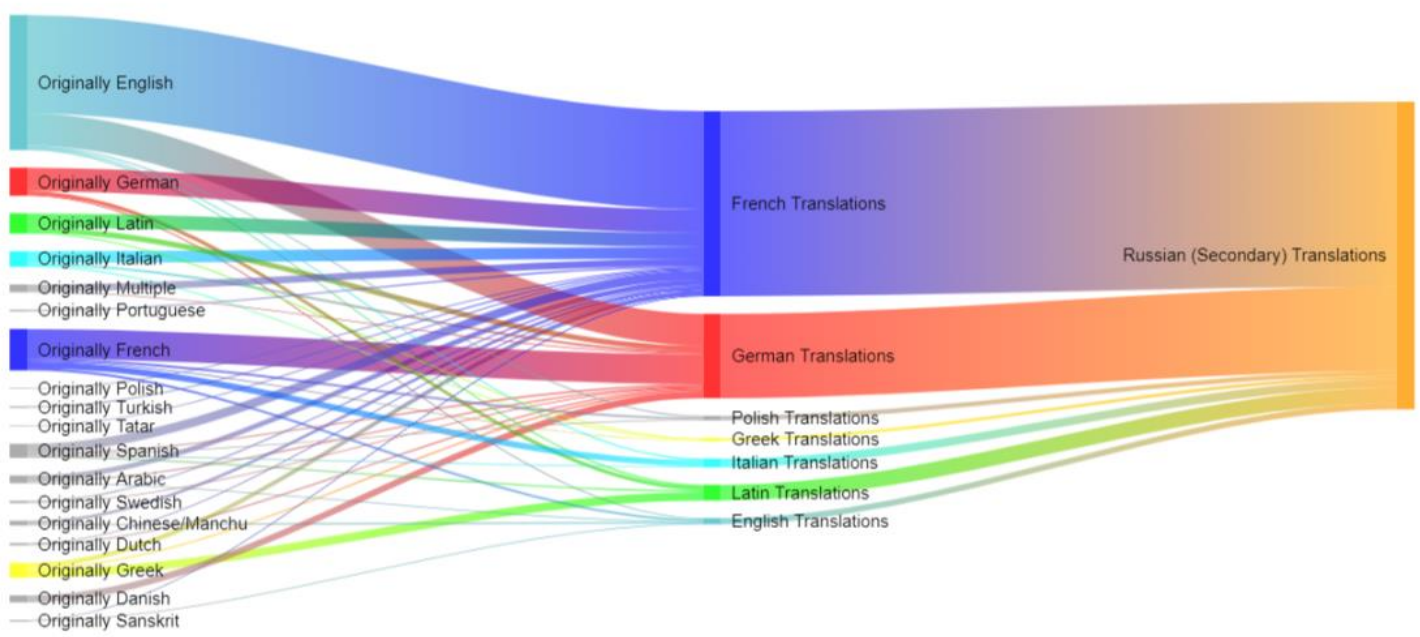


This data can hardly be compared to the data from other language communities in Europe: for some, to the best of our knowledge, there is no precise data of the sort, for others (e.g. the French book market) ${ }^{16}$ the very definition of what is understood and counted as a book is rather different, which does not allow us to make any close comparisons ${ }^{17}$ Interest in French book production began earlier in Western Europe, but generally the increase and the leading positions of translations from French do not seem particular to Russia. The same can be said about the role of French as an intermediary language.

The data we used, apart from our own database, derived from the electronic catalogs of the Russian National Library. This raw data needs to be double-checked and that is what we are currently doing. This is a very long undertaking, but we hope that it will allow researchers to get precise and trustworthy statistical data on a variety of questions related to general book production in Russia and particularly on translated socio-political literature.

\section{Future Development}

How do we intend to develop our database in the future? First, we would like to increase the number of translations by providing an enlarged sample of texts. We have been constantly uploading new excerpts since we launched the website. Our database covers the great majority of published texts that can be qualified as "political," but it does not include journal publications. This is an important issue, as many translations were published in journals in Russia, particularly in the second half of the eighteenth century, so we intend to try and locate political translations in journals.

With the help of Vadim Popov, the manager of public relations and digital humanities at the GHI, we have already begun an initiative to allow users to view the results of our research. This is a very important aspect of the project, because it is hoped that it will give us an idea of the evolution of the translation of political texts against the backdrop of the number of published works in general.

\footnotetext{
${ }^{16}$ See, for example, François Furet, "La 'librairie' du royaume de France au 18 e siècle," in Livre et société dans la France du XVIIIe siècle, eds. G. Bollème, J. Ehrard, F. Furet, D. Roche \& J. Roger (Paris: Mouton, 1965), 3-32; HenriJean Martin, "Une croissance séculaire," in Histoire de l'édition française, t. 2, Le livre triomphant, eds. Roger Chartier \& Henri-Jean Martin (Paris: Fayard/Cercle de la librairie, 1984), 113-127.

${ }^{17}$ See, for example, Claudine Adam, Les imprimeurs-libraires toulousains et leur production au XVIIIe siècle (17391788) (Toulouse : Presses universitaires du Midi, 2015), https://books.openedition.org/pumi/15354?lang=en.
} 